\title{
Physiological responses and scope for growth of Ruditapes decussatus from Ria Formosa, southern Portugal, exposed to increased ambient ammonia*
}

\author{
PAULA SOBRAL and SANDRA FERNANDES \\ IMAR - Instituto do Mar, Faculdade de Ciências e Tecnologia, Universidade Nova de Lisboa, Campus da Caparica, \\ 2829-516 Caparica, Portugal. E-mail: psobral@fct.unl.pt
}

\begin{abstract}
SUMMARY: In this study we investigate the effects of exposure to increased ambient ammonia-N concentrations as a cause of decreased scope for growth and mortality of $R$. decussatus during the summer months in Ria Formosa, southern Portugal. The physiological measurements were performed at $20{ }^{\circ} \mathrm{C}$ and average total ammonia-N concentrations (TA-N) were $9,48,85,134$ and $260 \mu \mathrm{mol} \mathrm{l}^{-1}$ (corresponding to $0.2,1.1,2.0,3.2$ and $6.2 \mu \mathrm{mol} \mathrm{l}^{-1} \mathrm{NH}_{3}$ ). No mortality was observed. Our results show that during short term exposure to TA-N concentrations $>48 \mu \mathrm{mol} \mathrm{l}^{-1}\left(1.1 \mu \mathrm{molNH}_{3}\right), R$. decussautus survives at the expense of energy reserves. No energy is available for growth and reproduction. Though it is uncertain how intermittent exposures during tidal cycles will affect the long-term survival of $R$. decussatus in the Ria Formosa, high ammonia concentrations together with unfavourable physical and chemical summer gradients in the sediment can clearly contribute to the high mortality that has been registered in recent years (Ferreira et al. 1989). The sensitivity of the physiological energetics approach and the need to assess tolerance of infaunal bivalves addressing endpoints that can provide insight into the condition for growth and reproduction of the population is stressed.
\end{abstract}

Key words: ambient ammonia, physiological energetics, scope for growth, Ruditapes decussatus.

RESUMEN: RESPUESTAS FISIOLÓGICAS Y CRECIMIENTO POTENCIAL DE RUdiTAPES DECUSSATUS EN Ria FoRMOSA, SUR DE PORTUGAL. - En este estudio se investigó el efecto de la exposición a concentraciones elevadas de amonio como causa del descenso en el crecimiento potencial y de la mortalidad de Ruditapes decussatus durante los meses de verano en Ria Formosa, Sur de Portugal. Las medidas fisiológicas se realizaron a $20^{\circ} \mathrm{C}$ y las concentraciones medias de amonio total (TA-N) fueron 9, 48, 85, 134 e $260 \mu \mathrm{mol} \mathrm{l}^{-1}$, (correspondientes a 0.2, 1.1, 2.0, 3.2 e $6.2 \mu \mathrm{mol} \mathrm{l}^{-1} \mathrm{NH}_{3}$ ). No se observaron mortalidades. Los resultados muestran que $R$. decussatus, durante exposiciones cortas a concentraciones de TA-N $>48 \mu \mathrm{mol} \mathrm{l}^{-1}\left(1.1 \mu \mathrm{molNH}_{3}\right)$, sobrevive utilizando sus reservas energéticas. No existiendo energía disponible para crecimiento y reproducción. Aunque los efectos a largo plazo de las exposiciones intermitentes de los ciclos de mareas a la supervivencia de $R$. decussatus en Ria Formosa se desconocen, con este trabajo podemos afirmar que las concentraciones elevadas de amonio, junto a los gradientes físico-químicos en sedimento poco favorables en épocas estivales, pueden contribuir a la elevada mortalidad de $R$. decussatus observada en años recientes. En este trabajo se aborda la sensibilidad de los estudios en energética fisiología y la necesidad de estudios en tolerancia de bivalvos de la infauna para definir respuestas indicadoras que permitan comprender las condiciones de crecimiento y de reproducción en poblaciones estresadas.

Palabras clave: amonio, energética fisiológica, crecimiento potencial, Ruditapes decussatus.

\section{INTRODUCTION}

The presence of ammonia is known to be toxic to many marine and estuarine fish and invertebrates.

*Received October 15, 2002. Accepted October 17, 2003.
Generally studies on the effects of ammonia toxicity have been performed within the scope of understanding and solving aquaculture problems raised by intensive farming of shrimp or prawns. These studies have investigated lethal effects (Chen et al., 1990; Frías-Espericueta et al., 1999), uptake and 
excretion of ammonia (Schmitt and Uglow, 1997; Chen and Chen, 1997) and the combined effects of ammonia and salinity (Chen et al., 1994; Lin and Chen, 2001). Sadok et al. (1995) examined the tolerance of the mussel Mytilus edulis to ambient ammonia.

Studies on ammonia toxicity towards infaunal species are scarce. However, concentrations of ammonia in the sediments can be high and variable, especially in situations in which high organic content and high temperatures clearly enhance anoxia in the upper sediment layers, leading to an increase in ammonia-N concentrations with depth, a typical pattern found in many coastal sediments (Koike and Sørensen, 1988).

The development of sediment toxicity tests with amphipods (Kohn et al., 1994, Moore et al., 1997) and the bivalve Mulinia lateralis (Huber at al., 1997) using mortality and growth as endpoints have provided information on tolerance to ammonia, but none has examined the effects of ambient ammonia on the physiological responses that can lead to decreased performance and ultimately death.

The clam Ruditapes decussatus is cultivated extensively on the intertidal mudflats of the Ria Formosa, a barrier island system in southern Portugal, with a production of 8000 tons per year, corresponding to $€ \sim 50$ million per year. Ninety percent of the production is exported (Ferreira et al., 1989). $R$. decussatus is thus an economically important species and clam farming is a very important activity for the nearby populations exploiting this resource.

High mortality of clams has been registered in recent years, especially in late summer (Ferreira et al., 1989). Some studies have addressed the effects of environmental factors such as hypoxia, anoxia and high temperatures on the physiological performance and their consequences on the scope for growth (SFG) of this species (Sobral and Widdows, 1997a,b). In fact these and other not yet evaluated factors may interact to decrease physiological performance.

Ammonia can accumulate in the Ria sediments due to the enhancement of denitrification when the intertidal mudflats are exposed to high summer temperatures at low tide. Falcão and Vale (1990) have found a sharp release rate of ammonia from the Ria sediments in the presence of $R$. decussatus. When the tide rises and clams start to feed they are exposed to high $\left(>100 \mu \mathrm{mol} \mathrm{l}^{-1}\right)$ ammonia concentrations that will eventually level off when tidal flushing promotes mixing at the sediment-water interface.

This study investigates the effects of exposure to ambient ammonia as a probable cause of decreased scope for growth and mortality of R.decussatus in the Ria Formosa during the summer months.

\section{MATERIALS AND METHODS}

Clams, $R$. decussatus, were collected in July 2000 in the Ria Formosa. All the organisms were brushed carefully to clean the shell and were allowed to bury in ammonia free fine sand collected at the Praia da Rainha on the Costa da Caparica. They were acclimatised for at least $48 \mathrm{~h}$ to laboratory conditions in a flow-through seawater system (salinity 35), under controlled temperature $\left(20 \pm 1^{\circ} \mathrm{C}\right)$ with gentle aeration, and fed with a culture of the diatom Phaeodactylum tricornutum ( $65 \pm 8 \%$ organic matter).

To evaluate general condition of the organisms a body condition index (BCI) was calculated as the dry weight: shell length ratio (Walne, 1972).

The animals used in the experiments had a shell length of $34.2 \pm 1.5 \mathrm{~mm}$ and a dry weight of $0.49 \pm 0.11 \mathrm{mg}(\mathrm{n}=54)$. Groups of 12 organisms were exposed to five total ammonia- $\mathrm{N}$ concentrations (ionised ammonia $\mathrm{NH}_{4}^{+}+$un-ionised ammonia

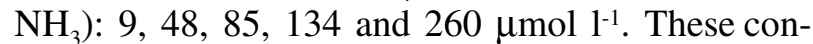
centrations were obtained by dilution of a stock solution of ammonium chloride in filtrated seawater $(0.45 \mu \mathrm{m})$. Solutions were aerated in 101 round flasks prior to the experiments. TA-N was determined by the phenol hypochlorite method of Solórzano (1969). The $\mathrm{pH}$ of each concentration was monitored during the experiments with an Orion ${ }^{\circledR} \mathrm{pH}$ electrode. The concentration of $\mathrm{NH}_{3}$ (the toxic un-ionised form of ammonia), was calculated according to the tables in Bower and Bidwell (1978), considering the average $\mathrm{pH}$ of 7.9 at $20^{\circ} \mathrm{C}$.

\section{Physiological measurements}

The SFG methodology is described in detail in Bayne et al. (1985). All physiological measurements (clearance rate, respiration and excretion) were performed in experimental chambers held in a flow-through temperature controlled $\left(20^{\circ} \mathrm{C}\right)$ water bath during exposure to ammonia. The working area was kept clean and free of dust and fumes so as to avoid contamination. All glassware used was decontaminated overnight with 1: $20 \mathrm{HCl}$. 
After the physiological measurements, the organisms were briefly frozen and the soft parts were removed and washed with ammonium formate $0.5 \mathrm{M}$ for salt removal. Dry weight was determined after drying at $60^{\circ} \mathrm{C}$ for $48 \mathrm{~h}$.

\section{Clearance rate measurements}

Clearance rate $\left(\mathrm{CR}, 1 \mathrm{~h}^{-1}\right)$ was measured in 11 glass beakers with a previously prepared solution of each TA-N concentration. Six beakers (with one organism each) and a control beaker (without organisms) were used. At the beginning of the test the microalgae P.tricornutum $\left(\sim 16000 \mathrm{cell} \mathrm{ml}^{-1}\right)$ was added to the beakers. To avoid algal cell deposition, agitation was provided through a gently rotating bar magnet. Samples of $20 \mathrm{ml}$ were collected with a syringe every $15 \mathrm{~min}$ over an hour. Microalgal cell concentrations were recorded as the average of three to four counts using a Coulter Counter ${ }^{\circledR}$ Mod 2 electronic particle counter. Clearance rate (CR) per unit time by individual was calculated using the following equation (Coughland,1969):

$$
\mathrm{CR}=\mathrm{V}\left(\ln \mathrm{C}_{1}-\ln \mathrm{C}_{2}\right) / \mathrm{t}
$$

where $\mathrm{V}$ is the volume of water used, $\mathrm{C}_{1}$ and $\mathrm{C}_{2}$ are the cell concentration between two sampling times and $\mathrm{t}$ is the time interval.

\section{Absorption efficiency measurements}

The absorption efficiency (Ae) was measured using the method of Conover (1966). Faeces were collected after clearance rate measurements by pipeting onto GF/C Whatman ${ }^{\circledR}$ pre-weighed filters. The $P$. tricornutum culture was filtered through $\mathrm{GF} / \mathrm{C}$ filters treated in the same way. Both were washed with $30 \mathrm{ml}$ of ammonium formate $0.5 \mathrm{M}$ to eliminate salt.

The organic content of food (F) and of faeces (E) was determined as the ash-free dry weight after ignition for $1 \mathrm{~h}$ at $450^{\circ} \mathrm{C}$ and Ae was determined using the expression

$$
\mathrm{Ae}=(\mathrm{F}-\mathrm{E}) \times 100 /[(1-\mathrm{E}) \mathrm{F}]
$$

\section{Absorption rate}

Absorption rate $\left(\mathrm{A}, \mathrm{mg} \mathrm{h}^{-1}\right)$ was calculated using the expression

$$
\mathrm{A}=\mathrm{C} \times \mathrm{Ae}
$$

where $\mathrm{C}$ is the consumption rate $\left(\mathrm{C}, \mathrm{mg} \mathrm{h}^{-1}\right)$ calculated from the $\mathrm{CR}\left(\mathrm{l} \mathrm{h}^{-1}\right)$ and the organic matter in the food absorbed $\left(\mathrm{mgl}^{-1}\right)$, and Ae is the absorption efficiency. Absorbed energy $\left(\mathrm{J} \mathrm{h}^{-1}\right)$ was calculated using the energy equivalent $1 \mathrm{mg}$ organic matter = $23 \mathrm{~J}$ (Widdows et al. 1979).

\section{Respiration rate measurements}

Before each respiration experiment the organisms were washed with seawater to remove faeces and other particles. Respiration rates $\left(\mathrm{R}, \mu \mathrm{mol} \mathrm{O} \mathrm{O}^{-1} \mathrm{~g}^{-1}\right)$ were measured individually in closed acrylic chambers of $\sim 800 \mathrm{ml}$ in a water bath at $20^{\circ} \mathrm{C}$. To avoid stratification gentle agitation was provided through a rotating bar magnet. Oxygen decline was monitored continuously with microcathode oxygen electrodes connected to a 928 System unit and software from Strathkelvin Instruments ${ }^{\circledR}$. Oxygen was never below $70 \%$ saturation. The individual rate of oxygen uptake $\left(\mathrm{R}, \mu \mathrm{mol} \mathrm{O} \mathrm{O}^{-1}\right)$ was calculated based on a 30 minute monitoring period using the expression

$$
\mathrm{R}=\left(\mathrm{C}_{\mathrm{to}}-\mathrm{C}_{\mathrm{t} 1}\right) \times \mathrm{V} \times 60 /\left(\mathrm{t}_{1}-\mathrm{t}_{0}\right)
$$

where $\mathrm{C}_{\mathrm{t}}$ is the concentration of oxygen in the water $\left(\mu\right.$ mol $\left.\mathrm{O}_{2} \mathrm{l}^{-1}\right)$ at time $\mathrm{t}, \mathrm{V}(\mathrm{l})$ is the volume of water in the respirometer chamber and $t_{0}$ and $t_{1}$ are the initial and end times (in minutes) of the measurement period. Energy lost through respiration $\left(\mathrm{J} \mathrm{h}^{-1}\right)$ was calculated using the energy equivalent $1 \mu \mathrm{mol} \mathrm{O} \mathrm{O}_{2}=0.456$ J (Gnaiger, 1983).

\section{Excretion rate measurements}

Excretion rates were measured individually by incubating each animal in a beaker for 1 hour in 100 $\mathrm{ml}$ of filtered $(0.45 \mu \mathrm{m})$ seawater in a water bath at $20^{\circ} \mathrm{C}$. For all measurements a control beaker was used. TA-N determinations were made by the phenol-hypochlorite method (Solorzano, 1969) and analysed with a UNICAM® 56254 UV/VIS spectrophotometer at $640 \mathrm{~nm}$.

The excretion rate $\left(\mathrm{U}, \mu\right.$ molTA- $\left.\mathrm{N} \mathrm{h}^{-1}\right)$ was calculated using the expression

$$
\mathrm{U}=(\mathrm{T}-\mathrm{C}) \mathrm{x}(\mathrm{V} / 1000) / \mathrm{t}
$$

where $\mathrm{T}$ is the TA-N concentration in the individual beakers, $\mathrm{C}$ is the TA-N concentration in the control, 
$\mathrm{V}(\mathrm{ml})$ is the incubation volume and $\mathrm{t}$ is the incubation period. Energy lost through excretion $\left(\mathrm{J} \mathrm{h}^{-1}\right)$ was calculated using the energy equivalent $1 \mu \mathrm{mol} \mathrm{N}$ $\mathrm{NH}_{4}=0.349 \mathrm{~J}$ (Elliot and Davidson, 1985).

\section{Scope for growth}

The individual physiological rates were standardised to a body mass of $0.5 \mathrm{~g}$ dry weight, the average weight of clams in the experiment, using a standard weight exponent of 0.7 (Bayne and Newell, 1983; Sobral, 1995). Scope for growth $\left(\mathrm{J} \mathrm{h}^{-1}\right)$ was calculated using the balanced energy equation of Winberg (1960).

$$
\mathrm{SFG}=\mathrm{A}-(\mathrm{R}+\mathrm{U})
$$

\section{Statistical analysis}

Absorption, respiration and excretion rates and SFG were tested for normality and homogeneity of the variances and $\log$ transformed when needed (Zar, 1996). The significance of differences in absorption, respiration and excretion rates and in individual SFG for each of the TA-N concentrations was then determined through one-way ANOVA and a posteriori SNK multicomparisons test using STATISTICA $^{\mathrm{TM}}$ software.

\section{RESULTS}

TA-N concentrations in the experiment were 9 , $48,85,134$ and $260 \mu \mathrm{mol} \mathrm{l}^{-1}$, corresponding to 0.2 , $1.1,2.0,3.2$ and $6.2 \mu \mathrm{mol} \mathrm{l}^{-1} \mathrm{NH}_{3}$. These concentrations are averaged values from a range of concentrations at which the physiological measurements were effectively measured $(1-13,41-58,82-87,112-151$, 251-271 $\mu \mathrm{mol} \mathrm{l}^{-1}$ TA-N).

No mortality was observed. The first reaction of $R$. decussatus is to avoid exposure by closing their

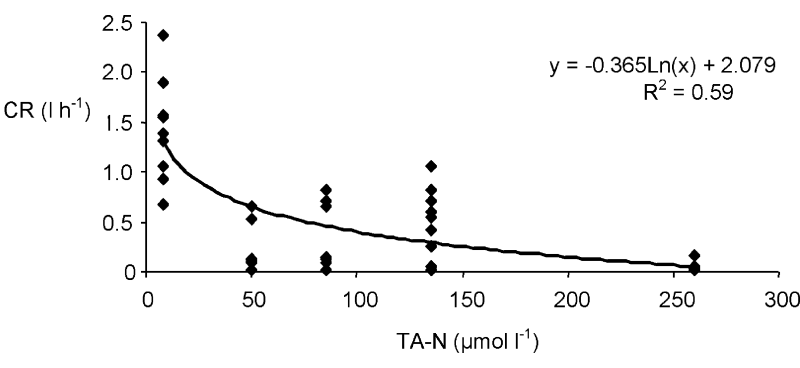

Fig. 1. - Clearance rate $\left(1 \mathrm{~h}^{-1}\right)$ for a standard $0.5 \mathrm{~g} \mathrm{dw}$ individual $R$. decussatus exposed to different TA-N concentrations $\left(\mu \mathrm{mol} \mathrm{l}^{-1}\right)$.

valves. Some animals would open slightly to allow only a small opening of the siphons and therefore their clearance rates were greatly reduced.

At the higher TA-N concentration $64 \%$ of the organisms remained active by pumping water at a lower rate. Body condition index as the ratio dry weight $(\mathrm{mg})$ : shell length $(\mathrm{mm})$ showed a mean value of $1.42 \pm 0.27,(n=54)$ and was $17 \%$ higher than that found in a previous study also performed in summer by Sobral (1995).

Individual performance varied with increasing TA-N concentrations, as shown in Figures 1-3, and on many occasions it was not possible to measure absorption, respiration and excretion rates on the same individuals due to valve closure. Values for SFG, absorption, respiration and excretion rates for each TA-N concentration are shown in Table 1.

Absorption efficiency varied between 26.7 and $69.3 \%$ and was lowest at the highest ammonia concentration.

Increasing concentrations of TA-N above 48 $\mu \mathrm{mol} \mathrm{l}^{-1}\left(1.1 \mu \mathrm{molNH}_{3}\right)$ showed a significant effect on the decrease of SFG $(p<0.001)$ that was always negative, except in one animal. This is the result of the reduced clearance rates, which follow a logarithmic decrease shown in Figure 1. Clearance rates were also significantly different above $48 \mu \mathrm{mol} \mathrm{l}^{-1}$ $(p<0.001)$.

Respiration rates at $85 \mu \mathrm{mol} \mathrm{l^{-1 }}$ TA-N were significantly higher $(p<0.05)$ than at other concentra-

TABLE 1. - Components of the energy budget and scope for growth ( $\mathrm{J} \mathrm{h}^{-1}$ mean $\left.\pm \mathrm{SE}\right)$ for a standard $0.5 \mathrm{~g}$ dw Ruditapes decussatus exposed to ammonia-N concentrations $\left(\mu \mathrm{mol} \mathrm{l}^{-1}\right)$. C, energy consumed; A, energy absorbed; R, energy loss through respiration; U, energy loss through excretion. (in brackets the number of individuals measured)

\begin{tabular}{|c|c|c|c|c|c|c|}
\hline $\begin{array}{l}\text { Ammonia-N } \\
\mu \mathrm{mol} \mathrm{l}^{-1}\end{array}$ & $\begin{array}{c}\mathrm{C} \\
\left(\mathrm{J} \mathrm{h}^{-1}\right)\end{array}$ & $\underset{\%}{\mathrm{Ae}}$ & $\underset{\left(\mathrm{J} \mathrm{h}^{-1}\right)}{\mathrm{A}}$ & $\underset{\left(\mathrm{J} \mathrm{h}^{-1}\right)}{\mathrm{R}}$ & $\underset{\left(\mathrm{J} \mathrm{h}^{-1}\right)}{\mathrm{U}}$ & $\begin{array}{l}\mathrm{SFG} \\
\left(\mathrm{J} \mathrm{h}^{-1}\right)\end{array}$ \\
\hline 9 & $28.3 \pm 3.83(9)$ & 66.4 & $18.79 \pm 2.59(9)$ & $11.57 \pm 1.72(11)$ & $0.39 \pm 0.06(11)$ & 6.83 \\
\hline 48 & $3.21 \pm 1.34(6)$ & 69.3 & $2.23 \pm 0.93$ & $7.77 \pm 0.86(12)$ & $0.22 \pm 0.08(6)$ & -5.77 \\
\hline 85 & $6.38 \pm 2.61(7)$ & 60.2 & $3.84 \pm 1.47(7)$ & $16.36 \pm 1.00(6)$ & $0.40 \pm 0.19$ & -12.92 \\
\hline 134 & $19.12 \pm 3.57(11)$ & 53.2 & $10.18 \pm 2.60$ & $12.22 \pm 1.50(12)$ & $0.29 \pm 0.09(9)$ & -2.34 \\
\hline 260 & $1.46 \pm 0.44(8)$ & 26.7 & $0.39 \pm 0.47(8)$ & $10.58 \pm 1.06(12)$ & $0.03 \pm 0.009(3)$ & -10.2 \\
\hline
\end{tabular}




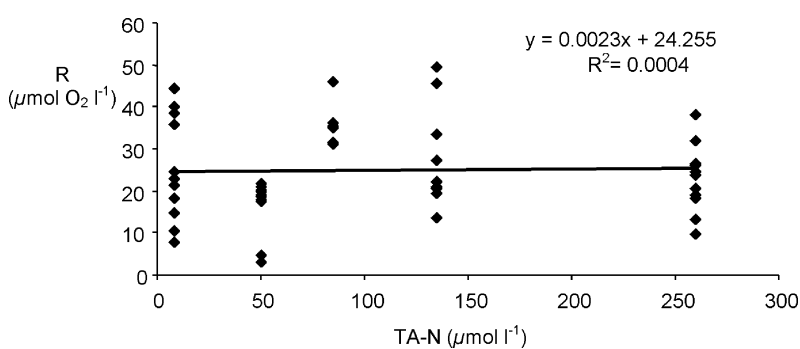

FIG. 2. - Respiration rate $\left(\mu \mathrm{mol} \mathrm{O}_{2} \mathrm{~h}^{-1}\right)$ for a standard $0.5 \mathrm{~g} \mathrm{dw}$ individual $R$. decussatus exposed to different TA-N concentrations $\left(\mu \mathrm{mol} \mathrm{l}^{-1}\right)$.

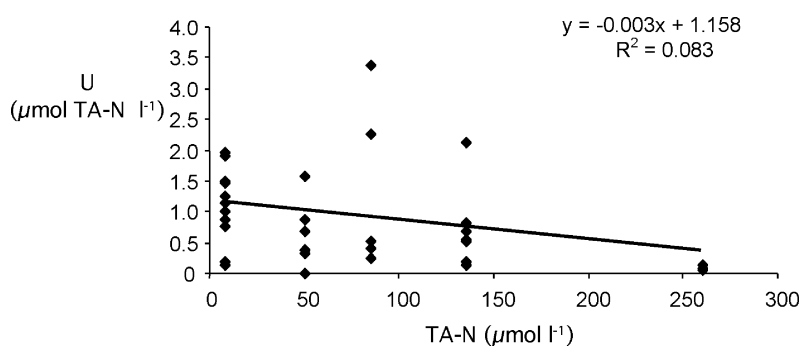

FIG. 3. - Excretion rate ( $\mu$ mol TA-N ${ }^{-1}$ ) for a standard $0.5 \mathrm{~g} \mathrm{dw}$ individual $R$. decussatus exposed to different TAN concentrations $\left.(\mu \mathrm{mol} \mathrm{1})^{-1}\right)$.

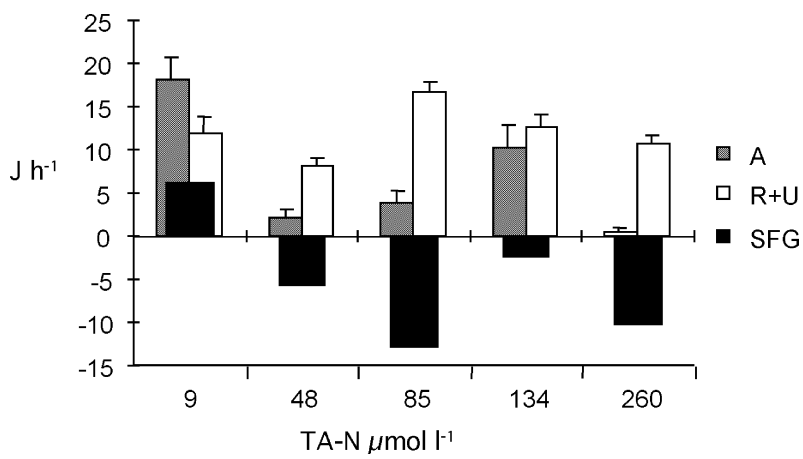

FIG. 4. - Components of the energy budget $\left(\mathrm{J} \mathrm{h}^{-1}\right.$, mean $\left.\pm \mathrm{SE}\right)$ and scope for growth for a standard $0.5 \mathrm{~g} \mathrm{dw} R$. decussatus exposed to different TAN concentrations $\left(\mu \mathrm{mol} \mathrm{l}^{-1}\right)$. A, energy absorbed; R + $\mathrm{U}$, energy lost through respiration (R) and excretion (U); SFG, scope for growth. tions, accounting for the lowest SFG value registered. High variability between individuals resulted in no correlation between respiration rates and increased TA-N (Fig. 2). Excretion rates were not significantly affected by increased TA-N concentrations $(p>0.05)$ and a weak negative relation could be found between excretion and increased ammonia exposure (Fig. 3).

Energy budgets (energy gain from food and loss from respiration and excretion) for each TA-N concentration and resulting SFG values are illustrated in Fig. 4. Energy requirements in terms of metabolism (respiration and excretion) were between 0.6 and 27 times the energy gain, being aggravated by increasing TA-N concentrations.

The amount of energy lost through respiration and excretion was $\sim 64$ and $\sim 2 \%$ respectively at the lowest concentration and increased sharply for higher TA-N concentrations. The group of animals exposed to $134 \mu \mathrm{mol} \mathrm{l}^{-1} \mathrm{TA}-\mathrm{N}$ was able to cope better with ammonia exposure, resulting in a higher but still negative value of SFG. These animals had a $30 \%$ higher BCI than the other animals.

Table 2 gives the results from one-way ANOVAs and the SNK test on the effect of TA-N concentrations on energy gain (A) and loss (R and $\mathrm{U})$ of $R$. decussatus.

\section{DISCUSSION}

The integrated physiological responses of $R$. decussatus were sensitive to the environmental realistic concentration levels of TA-N used in this study. In fact, ammonia concentrations used are very low when compared to those used by authors concerned

TABLE 2. - One-way ANOVA summary of the effect of ammonia-N on the physiological responses of $R$. decussatus (CR, energy absorbed; $\mathrm{R}$, energy loss through respiration; U, energy loss through excretion; and SFG, scope for growth) and a posteriori SNK test. (Concentrations not underlined by the same line are significantly different at $\alpha=0.05$ )

\begin{tabular}{|c|c|c|c|c|c|}
\hline Source of variation & df & SS & MS & $\mathrm{F}$ & $p$ \\
\hline \multicolumn{6}{|l|}{$\mathrm{CR}$} \\
\hline Ammonia-N conc & 4 & 9.58 & 2.39 & 19.40 & $<0.0001$ \\
\hline Error & 35 & 4.32 & 0.12 & & \\
\hline SNK test (conc $\mu \mathrm{mol} \mathrm{l}^{-1}$ ) & $\underline{9} \underline{4885134260}$ & & & & \\
\hline \multicolumn{6}{|l|}{$\underline{\mathrm{R}}$} \\
\hline$\overline{\text { Ammmonia-N conc }}$ & 4 & 1536.85 & 384.21 & 4.47 & $<0.01$ \\
\hline Error & 48 & 4121.5 & 85.87 & & \\
\hline SNK test (conc $\mu \mathrm{mol} \mathrm{l}^{-1}$ ) & $\underline{948134260} \underline{85}$ & & & & \\
\hline \multicolumn{6}{|l|}{$\mathrm{U}$} \\
\hline$\overline{\text { Ammonia- } \mathrm{N} \text { conc }}$ & 4 & 3.94 & 0.98 & 1.64 & n.s. \\
\hline Error & 29 & 17.40 & 0.60 & & \\
\hline
\end{tabular}


with defining acute toxicity and lethal concentrations of ammonia. For instance, Huber at al. (1997), working with the infaunal bivalve M. lateralis, used TA-N concentrations in the range 0 to $6 \mathrm{mmol} \mathrm{l}^{-1}$.

$R$. decussatus was able to cope with TA-N concentrations of up to $263 \mu \mathrm{mol} \mathrm{l}^{-1}$ and no mortality occurred. Negative values of SFG, however, imply that during short exposure the animals were using their body reserves to obtain the energy they need to survive.

The marked decline in SFG due to exposure to increased TA-N concentrations $\geq 48 \mu \mathrm{mol} \mathrm{l}^{-1}$ is mainly caused by decreased absorption rates resulting from narrow opening of the siphons and slow pumping. It has been shown in several SFG studies (Smaal and Widdows, 1994) that feeding is the most sensitive component of this stress index.

Though we could not detect significant differences among excretion rates, excretion by $R$. decussatus was lowest at the highest ammonia concentration, probably as a result of reduced active transport across the gills against the gradient, a process known to occur in fish and aquatic invertebrates (Kormanik and Cameron, 1981).

Uptake of ambient ammonia at concentrations $>100 \mu \mathrm{mol} \mathrm{l}^{-1}$ after 5 min exposure was observed in M. edulis (Sadok et al., 1995) along with normal pumping behaviour and no reported mortality, leading the authors to consider this species to be ammonia tolerant.

Huber et al. (1997), working with M. lateralis, and Moore et al. (1997), using the amphipod Leptocheirus plumulosus in sediment toxicity testing, reported no observed effects on growth at TA-N concentrations of $<100 \mathrm{mmol} \mathrm{l}^{-1}$ and $0.7 \mathrm{mmol} \mathrm{l}^{-1}$ respectively.

Our results, however, show that the short time exposure $(\sim 3 \mathrm{~h}$ during the physiological measurements) of $R$. decussatus to much lower concentrations of TA-N $\left(48 \mu \mathrm{mol} \mathrm{l} 1^{-1}\right.$ or $1.1 \mu \mathrm{mol} \mathrm{l}^{-1} \mathrm{NH}_{3}$ ) resulted in physiological stress. Negative values of SFG at concentrations of $48 \mu \mathrm{mol} 1^{-1}$ TA-N and higher imply that no energy is available for growth and reproduction. This can ultimately compromise survival.

Previous work has shown that $R$. decussatus is particularly sensitive to hypoxia, anoxia and the high temperatures that may develop in the sediments of the Ria Formosa in the summer months (Sobral and Widdows, 1997a, b).

In this study animals exposed to the lowest TA$\mathrm{N}$ concentration showed a higher SFG $\left(6.1 \mathrm{~J} \mathrm{~h}^{-1}\right)$ for the same time of the year than the one found by Sobral and Widdows (1997b), $3.9 \mathrm{~J} \mathrm{~h}^{-1}$, for the same temperature. Energy lost through respiration and excretion $(\sim 66 \%)$ at the lowest concentration is within the values found previously by the same authors.

Variability of physiological responses was obvious, and it was not possible to relate TA-N concentrations to metabolic expenditure measured by respiration rate. The high body condition index registered for the group of animals exposed to $134 \mathrm{TA}-\mathrm{N} \mu \mathrm{mol}$ $1^{-1}$ seems to be related to higher tolerance to stress, as shown by the less negative SFG.

In spite of the variability of individual responses, the balance between energy acquisition and loss becomes negative with increasing TA-N concentrations ( $>48 \mu \mathrm{mol} \mathrm{l} \mathrm{l}^{-1}$, Fig. 4 ), resulting in higher vulnerability of $R$. decussatus.

The sharp release in ammonia (>100 $\left.\mu \mathrm{mol} \mathrm{l}^{-1}\right)$ from the Ria sediments when the tide rises, demonstrated by Falcão and Vale (1990), as well as unfavourable physical and chemical summer gradients in the sediment can certainly contribute to a reduced performance of the clams.

However, it remains uncertain how short-term variations in ammonia concentrations and intermittent exposure, during repeated tidal cycles, will affect the long-term survival of $R$. decussatus in the Ria Formosa.

These findings stress the sensitivity of the physiological energetics approach and the need to assess tolerance of infaunal bivalves by addressing endpoints that can provide insight on conditions for growth and reproduction of the population before mortality occurs.

\section{ACKNOWLEDGEMENTS}

This work was part of a project funded by the National Foundation for Science and Technology under the reference PRAXIS/C/BIA/14220/1998. S. Fernandes was supported by grant BTI/17285/98 under the PRAXIS XXI programme.

\section{REFERENCES}

Bayne, B.L., D.A. Brown, K. Burns, R.D. Dixon, A. Ivanovici, D.R. Livingston, D.M. Lowe, M.N. Moore, A.R.D. Stebbing and J. Widdows, (eds.) 1985. The effects of stress and pollution on marine animals. Praeger Publ. New York.

Bower, C.E. and J.P. Bidwell. - 1978. Ionization of ammonia in seawater: effects of temperature, $\mathrm{pH}$ and salinity. J. Fish. Res. 
Board Can., 35: 1012-1016.

Chen, J.C., Y.Y. Ting, J.N. Lin and M.N. Lin. - 1990. Lethal effects of ammonia and nitrite in Penaeus chinensis juveniles. Mar. Biol., 107: 427-431.

Chen, J.-C., C.-T. Chen and S.-Y. Cheng. - 1994. Nitrogen excretion and changes of hemocyanin, protein and free amino acid levels in the hemolymph of Penaeus monodon exposed to different concentrations of ambient ammonia-N at different salinity levels. Mar. Ecol. Progr. Ser., 110: 85-94.

Chen, J.-C. and J.-M. Chen. - 1997. Arginase specific activity and nitrogenous excretion of Penaeus japonicus exposed to elevated ambient ammonia. Mar. Ecol. Progr. Ser., 153: 197-202.

Conover, R..J. - 1996. Assimilation of organic matter by zooplankton. Limnol. Oceanogr., 11: 338-345.

Coughland, J. - 1969. The estimation of filtering rate from the clearing of suspensions. Mar. Biol., 2: 356-368

Elliot, J.M. and W. Davidson. - 1985. Energy equivalents of oxygen consumption in animal energetics. Oecologia (Berl.), 19: 195-201.

Falcão, M. and C. Vale. - 1990. Study of the Ria Formosa ecosystem: benthic nutrient remineralization and tidal variability of nutrients in the water. Hydrobiol., 207: 137-146.

Ferreira, A.M., C. Vale, C. Cortesão, L. Pacheco, M. Falcão, O. Castro and R. Cachola. - 1989. Mortalidade da ameijoa Ruditapes decussatus na Ria Formosa Algarve. Relat. Téc. Cient. INIP, 10.

Frías-Espericueta, M.G., M. Harfush-Melendez, J.I. Osuna-López and F. Páez-Osuna. - 1999. Acute toxicity of ammonia to juvenile shrimp Litopenaeus vannamei Boone. Bull. Environ. Toxicol., 62: 646-652.

Gnaiger, E. - 1983. Heat dissipation and energetic efficiency in animal anoxibiosis: Economy contra power. J. Exp. Zool., 228: 471-490.

Huber, M., M.C. Pelletier, J.B. Charles and R.M. Burgess. - 1997. Ammonia tolerance of the bivalve Mulinia lateralis. Sublethal sediment toxicity test. Bull. Environ. Toxicol., 59: 292-297.

Kohn, N.P., J.Q. Word, D.K. Niyogi, L.T. Ross, T. Dillon and D.W. Moore. - 1994. Acute toxicity of ammonia to four species of marine amphipod. Mar. Env. Res., 38: 1-15.

Koike, I. and J. Sørensen. - 1988. Nitrate reduction and denitrification in marine sediments. In: T.H. Blackburn and J. Sørensen (eds.), Nitrogen cycling in coastal marine environments. SCOPE, pp. 251-273. John Wiley and Sons. New York.

Kormanik, G.A. and J.N. Cameron. - 1981. Ammonia excretion in animals that breathe water: a review. Mar. Ecol. Lett., 2: 11-23.

Lin, Y.C. and J.C. Chen. - 2001. Acute toxicity of ammonia on Litopenaeus vannamei Boone juveniles at different salinity levels. J. Exp. Mar. Biol. Ecol., 259: 109-119.

Moore, D.W. T.S. Bridges, B.R. Gray and B.M. Duke. - 1997. Risk of ammonia toxicity during sediment bioassays with the estuarine amphipod Leptocheirus plumulosus. Env. Toxicol. Chem., 16: 1020-1027.

Sadok, S., R. Uglow and S. Haswell. - 1995. Fluxes of haemolymph ammonia and free amino acids in Mytilus edulis exposed to ammonia. Mar. Ecol. Progr. Ser., 129: 177-187.

Schmitt, A.C. and R.F. Uglow. - 1997. Effects of ambient ammonia levels on the blood ammonia, ammonia excretion and heart and scaphognathite rates of Nephrops norvegicus. Mar. Biol., 127: 411-418

Smaal, A.C. and J. Widdows. - 1994. The scope for growth of bivalves as an integrated response parameter in biological monitoring. In: K. Kramer (ed.), Biomonitoring of coastal waters and estuaries, pp. 243-262. CRC Press, London.

Sobral, P. - 1995. Ecophysiology of Ruditapes decussatus. PhD thesis. Univ. Nova de Lisboa, Lisboa.

Sobral, P. and J. Widdows. - 1997a. The influence of hypoxia and anoxia on the physiological responses of the clam Ruditapes decussatus L. from southern Portugal. Mar. Biol., 127: 455-461.

Sobral, P. and J. Widdows. - 1997b. Effects of elevated temperatures on the physiological responses and resistance to air exposure of the clam Ruditapes decussatus, from southern Portugal. Sci. Mar., 61: 163-171.

Solórzano, L. - 1969. Determination of ammonia in natural waters by the phenol hypochlorite method. Limnol. Oceanogr., 14: 779-801.

Walne, P.R. - 1972. The influence of current speed, body size and water temperature on the filtration rates of five species of bivalves. J. mar. biol. Ass. UK, 52: 345-374.

Widdows, J., P. Fieth and C.M. Worrall. - 1979. Relationships among seston available food and feeding activity in the common mussel Mytilus edulis. Mar. Biol., 50: 195-207.

Winberg, G.G. - 1960. Rate of metabolism and food requirement of fishes. Fish. Res. Board Can., 194: 202-211.

Zar, J.H. - 1996. Biostatistical analysis. $3^{\text {rd }}$ ed. Prentice-Hall International, New York.

Scient. ed.: C. Richardson 